\title{
PSIKOEDUKASI "PEPRO" UNTUK MENURUNKAN PROKRASTINASI AKADEMIK DENGAN MENGGUNAKAN MANAJEMEN WAKTU PADA SISWA SISWI SMP DAN SMA/SMK
}

\author{
Luh Nyoman Alit Saraswati Sarasija ${ }^{1}$, Anindya Ayu Nariswari ${ }^{2}$, Dinda Aisha \\ Dewanggana ${ }^{3}$, Venya Alya Arghita, Tyvania Shalsabilla Wilhelmina Patty ${ }^{5}$, Harijanto \\ Tjahjono $^{6}$ \\ Email: ayuanindya66@gmail.com ${ }^{2}$ \\ Fakultas Psikologi, Universitas Surabaya $a^{1,2,3,4,5,6}$
}

\begin{abstract}
Phenomenon that occurs in a job that should be able to be done on time is known as procrastination. To decrease the rate of procrastination, psychoeducation is carried out time management related to prioritization techniques and behavioral consistency. The results of this psychoeducation showed that students can make techniques for making 4 Quadrants Covey, To Do List and choice techniques against organizing. In order to see the changes of student's behavior, it's necessary to take control regularly to see their consistency and do some follow up five days after psychoeducation is held. The result of giving psychoeducation caused an increasing post-test rate by $30 \%$ from pre-test. This indicates that the rate of procrastination was increasing and giving the time management methods to the Junior High School and Senior High School students was not effective enough to decrease their procrastination. The increasing score on the post-test caused by lots of item that were given so that the participants was not too aware about their real condition when they answered. Based on the interview after do the post-test, some participants said that making a study schedule was not an usual habit for them, they prefer to do without a daily goals and school give them lots of assignments so it was also led the increasing score on post-test result.
\end{abstract}

Keyword: student, procrastination, time management

\begin{abstract}
Abstrak
Fenomena menunda- nunda suatu pekerjaan yang seharusnya dapat dikerjakan secara tepat waktu dikenal dengan sebutan prokrastinasi. Untuk menurunkan tingkat prokrastinasi, maka dilakukan psikoedukasi mengenai manajemen waktu terkait teknik penentuan skala prioritas dan menumbuhkan konsistensi perilaku. Hasil dari psikoedukasi ini menunjukkan jika peserta didik dapat membuat teknik pembuatan 4 Kuadran Covey, To Do List dan teknik pilihan terhadap pengorganisasian. Guna melihat perubahan perilaku peserta didik maka perlu melakukan pemantauan secara berkala untuk melihat konsistensi perilaku dan juga melakukan follow up pada lima hari setelah diadakan psikoedukasi. Hasil dari pemberian psikoedukasi ini menyebabkan angka post-test meningkat sebesar $30 \%$ dari hasil pre test. Hal ini menandakan bahwa tingkat prokrastinasi meningkat dan pemberian manajemen waktu pada siswa SMP dan SMA/SMK belum cukup efektif untuk menurunkan perilaku prokrastinasi. Peningkatan angka pada hasil post-test disebabkan oleh banyaknya jumlah butir yang diberikan pada saat post-test sehingga peserta tidak memperhatikan kondisi yang sebenarnya yang dirasakan pada saat menjawab. Berdasarkan hasil wawancara dari beberapa peserta didapatkan bahwa mereka belum terbiasa untuk membuat jadwal belajar, lebih menyukai bekerja dengan tidak memiliki target setiap harinya dan beban tugas yang diberikan sekolah terlalu banyak sehingga hal ini juga memicu meningkatnya angka pada hasil post-test.
\end{abstract}

Kata kunci: siswa, prokrastinasi, manajemen waktu

\section{PENDAHULUAN}

Siswa atau peserta didik merupakan komponen dalam sistem pendidikan, yang selanjutnya akan diproses dalam proses pendidikan, sehingga menjadi individu berkualitas yang sesuai dengan tujuan pendidikan Nasional (Oemar Hamalik dalam Tim Dosen Administrasi Pendidikan UPI, 2009). Siswa yang dimaksud merupakan pelajar sekolah menengah pertama (SMP), sekolah menengah atas (SMA) dan 
sekolah menengah kejuruan (SMK). Para siswa menuntut ilmu pengetahuan untuk mencapai pemahaman ilmu yang telah diaplikasikan. Siswa adalah mereka yang mengikuti pembelajaran di sekolah yang sebelumnya telah diserahkan serta diamanahkan oleh orangtua dengan tujuan menjadi individu yang berwawasan luas, memiliki pengetahuan, keterampilan, akhlak mulia, pengalaman dan mandiri.

Seorang siswa bertanggung jawab untuk dapat menjalani proses belajar disekolah dengan baik. Menurut Prayitno (dalam Hastuti et al, 2019) menyelesaikan tugas merupakan salah satu bagian dari proses pembelajaran. Melalui tugas yang diberikan siswa harus mencari bahan ajar atau materi, mempelajarinya dan memahami lebih lanjut. Mengerjakan tugas tugas tertentu dapat memperoleh pemahaman dan keterampilan baru sesuai dengan materi tugas. Berdasarkan hasil wawancara kepada 15 orang siswa menyetujui bahwa tugas merupakan hal yang berkaitan dengan proses pembelajaran dan juga hal yang sering mereka dapatkan saat bersekolah. Terlebih lagi dengan adanya sistem pembelajaran jarak jauh yang sudah diterapkan 6 bulan terakhir ini, sistem ceramah guru tergantikan oleh tugas yang diberikan pihak sekolah.
Pandemi Covid-19 yang terjadi di Indonesia banyak berdampak pada kehidupan masyarakat, tidak terkecuali pada para siswa SMP, SMA maupun SMK. Hal ini berpengaruh pada kebijakan sekolah online, yaitu kegiatan belajar mengajar dilakukan dari jarak jauh dengan alasan kesehatan. Hal ini membuat sekolah memberikan banyak tugas kepada siswa dengan deadline pengumpulan yang singkat dan juga tingkat kesulitan soal yang beragam. Sistem ini memberikan tekanan tersendiri kepada siswa, akibatnya siswa menunda pekerjaan dan tugas sekolah mereka, merasa jenuh dalam belajar, dan kesulitan dalam mengatur prioritas waktu.

\section{KAJIAN PUSTAKA}

Perilaku menunda suatu pekerjaan yang seharusnya dapat dikerjakan secara tepat waktu disebut dengan prokrastinasi. Berdasarkan wawancara yang yang dilakukan peneliti kepada 15 orang siswa SMP, SMA dan SMK dari berbagai daerah mendapatkan hasil bahwa mereka cenderung sering menunda untuk mengerjakan tugas sekolah. Hal ini disebabkan oleh beberapa hal yaitu rasa malas, tugas yang diberikan dianggap sulit atau kurang dapat dimengerti, tugas yang diberikan terlalu banyak, mengerjakan tugas lain yang deadline nya lebih dekat, 
menunggu teman untuk mengerjakannya terlebih dahulu, menganggap tugas bukanlah hal yang penting dan melakukan kegiatan lain yang lebih menyenangkan seperti bermain game atau melihat sosial media. Saat mereka menunda mengerjakan tugas terdapat perasaan gelisah, cemas dan takut perilaku tersebut akan berpengaruh pada nilai akademiknya di sekolah.

Perilaku tersebut termasuk dalam perilaku prokrastinasi yang disampaikan oleh Ferrari dkk (dalam Fuziah, 2015), yaitu menunda memulai menyelesaikan tugas, terlambat untuk menyelesaikan tugas, terdapat kesenjangan waktu diharapkan dan waktu yang sesungguhnya untuk mengerjakan tugas dan melakukan aktivitas/hal lain yang lebih menyenangkan daripada menyelesaikan tugasnya. Untuk membantu mengatasi permasalah tersebut peneliti membuat psikoedukasi terkait manajemen waktu untuk menurunkan prokrastinasi (Pepro). Menggunakan manajemen waktu karena terdapat penelitian sebelumnya yang menyatakan bahwa manajemen waktu memiliki korelasi negatif dengan prokrastinasi (Kartadinata \& Tjundjing, 2008) sehingga jika para siswa dapat melakukan manajemen waktu tingkat prokrastinasi yang dimilikinya akan menurun.

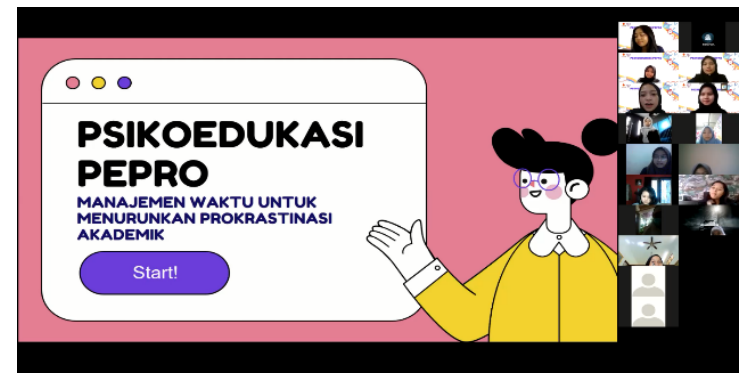

Gambar 1. Waktu pelaksanaan intervensi

Pelaksanaan psikoedukasi "PePro" untuk menurunkan prokrastinasi akademik dengan menggunakan manajemen waktu pada siswa SMP dan SMA dari berbagai daerah dilakukan sebagai usaha untuk dapat membantu siswa untuk menurunkan tingkat prokrastinasi yang dimiliki, terutama pada saat mengerjakan tugastugas sekolah. Terdapat beberapa tantangan yang dihadapi oleh peneliti pada proses psikoedukasi didalam masa pandemi ini, tantangan tersebut diantaranya adalah proses yang dilakukan tidak melalui tatap muka melainkan secara online sehingga peneliti perlu memikirkan cara yang efektif sekaligus menyenangkan untuk menyampaikan materi maupun mengajarkan sebuah keterampilan pada siswa yang posisinya jauh.

\section{METODE PENELITIAN}

Metode yang digunakan dalam psikoedukasi PePro meliputi ceramah (lecturing), pemutaran video (audio visual), refleksi diri (self reflection), paper assignment dan presentasi yang dilakukan 
oleh peserta. Guna memfasilitasi penyampaian materi yang baik dan menunjang bagi peserta, maka setiap rancangan sesi psikoedukasi PePro disusun menjadi:

\section{Input}

Input yakni meliputi penyampaian konsep, tujuan dan latar belakang dari penelitian ini dilaksanakan

2. Eksplorasi dan pembahasan materi Eksplorasi dan pembahasan materi disampaikan melalui metode ceramah, menonton video, refleksi diri, dan saling berbagi cerita (sharing)

3. Penerapan materi yang disampaikan (Paper assignment)

Guna membantu para peserta menerapkan materi yang disampaikan, maka peneliti merancang beberapa cara untuk menerapkan materi sesuai dengan aspek-aspek manajemen waktu seperti membuat tabel tujuan dan prioritas dengan berdasarkan teori Covey, membuat to do list serta membuat tabel reward dan konsekuensi.

Terdapat 5 materi dalam psikoedukasi ini yakni:

a. Materi I: Pemberian Materi Prokrastinasi Akademik dan Manajemen Waktu b. Materi II: Menetapkan Tujuan dan Prioritas

c. Materi III: Perencanaan dan Penjadwalan

d. Materi IV: Pilihan Terhadap Pengorganisasian

e. Materi V: Persepsi Kontrol atas Waktu dan Evaluasi

Materi I memberikan materi prokrastinasi dan manajemen waktu menggunakan slide power point, menampilkan video mengenai prokrastinasi, dan menggunakan aplikasi menti untuk sharing mengenai pengalaman mereka. Materi I ini membahas mengenai pengertian prokrastinasi, aspek prokrastinasi, dan dampak dari prokrastinasi. Selain itu, ada pembahasan terkait pengertian manajemen waktu dan aspek manajemen waktu. Pemberian materi menggunakan slide power point, menampilkan video mengenai prokrastinasi, dan juga menti untuk peserta sharing terkait pengalaman dalam melakukan prokrastinasi. Kegiatan ini dilakukan melalui aplikasi zoom pada tanggal 27 September 2020.

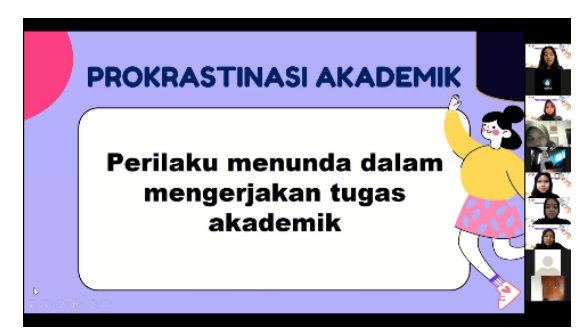



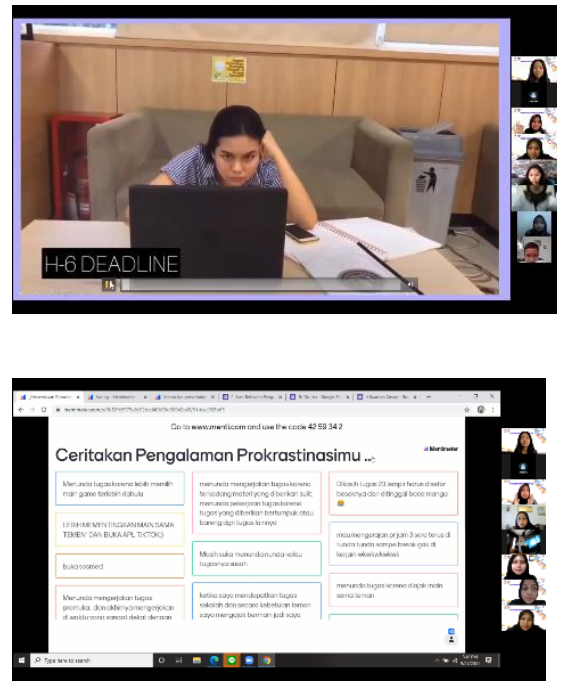

Gambar 2. Pelaksaan intervensi pada bagian materi I

Pada materi II yakni pemberian materi terkait aspek pertama dalam manajemen waktu yaitu menetapkan tujuan dan prioritas. Dalam tahap ini dijelaskan pengertian dari aspek menetapkan tujuan dan prioritas melalui slide power point dan memberikan penjelasan terkait kuadran milik Covey guna menentukan kegiatan berdasarkan kepentingan dan kegentingan. Selain itu, peserta juga diajak untuk menerapkan kuadran tersebut dengan mengisi sesuai kegiatan masing-masing melalui google form.

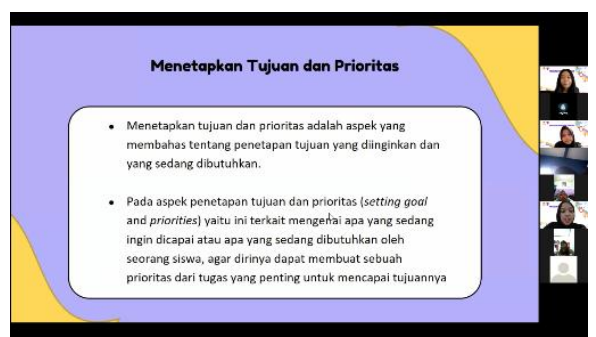

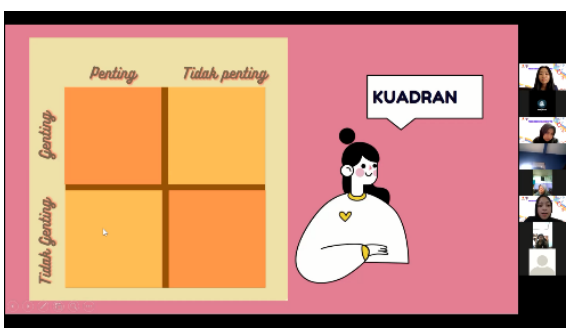
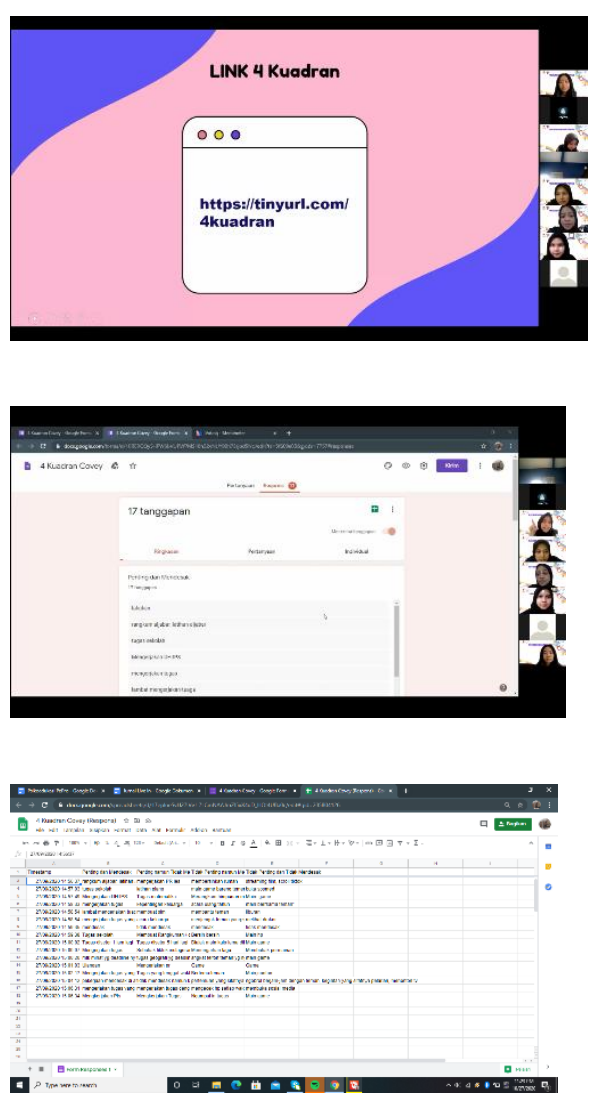

Gambar 3. Pelaksaan intervensi pada bagian materi II

Selanjutnya pada materi III yaitu memberikan materi aspek kedua dari manajemen waktu yaitu perencanaan dan penjadwalan. Pada tahap ini peserta diberi penjelasan terkait apa itu perencanaan dan penjadwalan melalui slide power point. Selain itu, peserta juga dikenalkan contoh bagaimana mengatur kegiatan sesuai kepentingan dan kegentingan yang sudah dicantumkan di tahap sebelumnya. Setelah 
itu, peserta diberi kesempatan untuk mengatur jadwalnya sendiri sesuai kegiatannya masing-masing menggunakan google form.
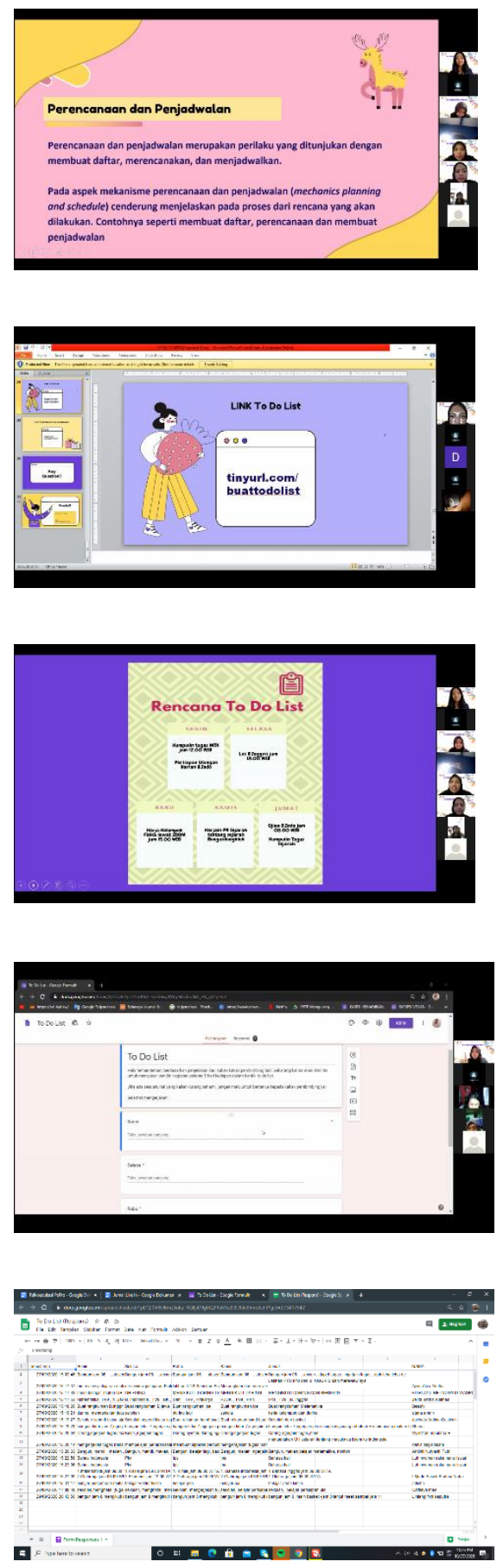

Gambar 4. Pelaksaan intervensi pada bagian materi III
Materi IV memberikan materi mengenai pilihan terhadap pengorganisasian yaitu aspek ketiga dari manajemen waktu. Pada tahap ini peserta diberikan materi mengenai pilihan terhadap pengorganisasian dan juga cara untuk mengisi tabel pengorganisasian (reward dan konsekuensi) atas kegiatan yang sudah dirancang melalui slide power point. Setelah itu, peserta diminta untuk membuka google form dan membuat tabel pengorganisasian sendiri.
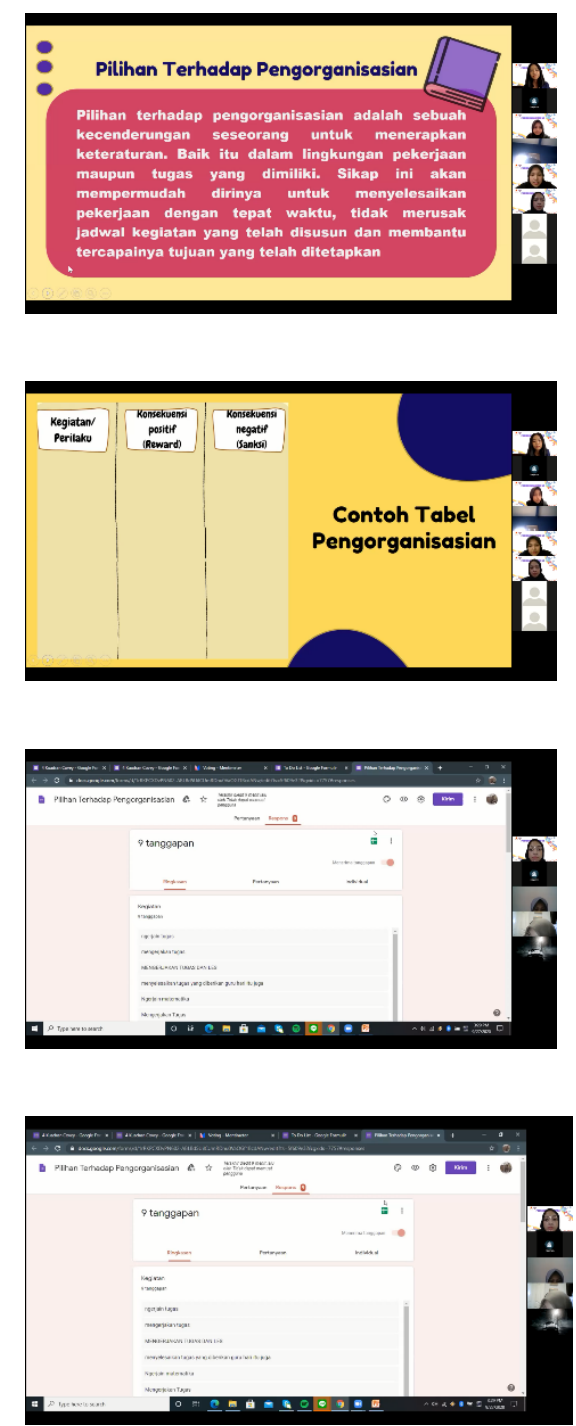


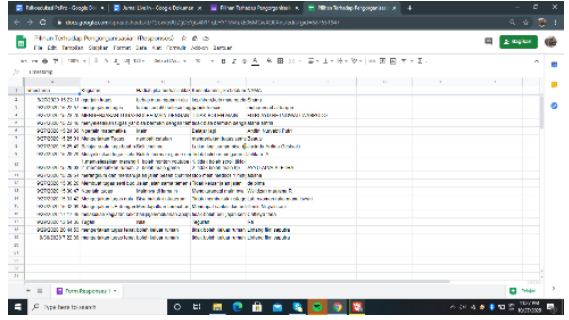

Gambar 5. Pelaksaan intervensi pada bagian materi IV

Materi terakhir yaitu mengenalkan aspek keempat dari manajemen waktu yaitu persepsi kontrol atas waktu dan evaluasi. Peserta diberikan pengertian bagaimana untuk memiliki kontrol atas waktu dan mengevaluasi melalui penjelasan yang disampaikan menggunakan slide power point.

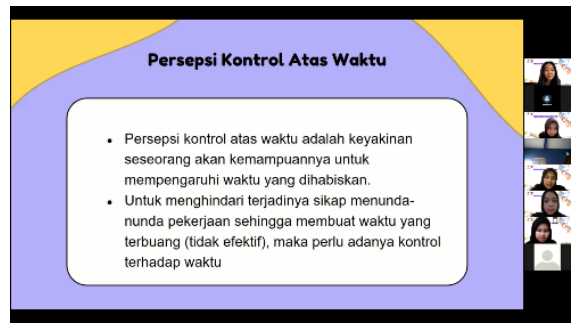

Gambar 6. Pelaksaan intervensi pada bagian materi $\mathrm{V}$

Pada kegiatan psikoedukasi ini telah dilakukan pengisian angket terkait data demografis peserta.

Tabel 1. Deskripsi data demografis tingkat pendidikan peserta psikoedukasi

\begin{tabular}{ccc}
\hline Pendidikan & Frekuensi & Persentase \\
\hline SMP & 6 & $35,3 \%$ \\
SMA/SMK & 11 & $64,7 \%$ \\
\hline Total & 17 & $100 \%$ \\
\hline
\end{tabular}

Tabel 2. Deskripsi data demografis usia peserta psikoedukasi

\begin{tabular}{ccc}
\hline Usia & Frekuensi & Persentase \\
\hline 12 tahun & 3 & $17,6 \%$ \\
13 tahun & 2 & $11,8 \%$ \\
15 tahun & 5 & $29,4 \%$ \\
16 tahun & 5 & $29,4 \%$ \\
17 tahun & 2 & $11,8 \%$ \\
\hline Total & 17 & $100 \%$ \\
\hline
\end{tabular}

Tabel 3. Deskripsi data demografis jenis kelamin peserta psikoedukasi

\begin{tabular}{ccc}
\hline Jenis kelamin & Frekuensi & Persentase \\
\hline Laki-laki & 4 & $23,5 \%$ \\
Perempuan & 13 & $76,5 \%$ \\
\hline Total & 17 & $100 \%$
\end{tabular}

Diketahui dari tabel 1, peserta yang mengikuti psikoedukasi ini didominasi oleh kalangan SMA/SMK sehingga rata-rata peserta berusia $15-16$ tahun (lihat Tabel 2). Dalam pengadaan psikoedukasi ini juga lebih banyak diikuti oleh perempuan daripada laki-laki. Pengumpulan data ini dilakukan secara kuantitatif melalui google form yang dibagikan secara online.

\section{HASIL DAN PEMBAHASAN}

Proses penurunan prokrastinasi atau yang disingkat dengan "PePro" dilakukan dengan menghasilkan keterampilan dalam beberapa hal. Diantaranya yaitu :

1. Teknik Pembuatan 4 Kuadran Covey bagi seluruh peserta psikoedukasi yaitu siswa SMP, SMA maupun SMK. Teknik 4 
Kuadran ini diperlukan untuk menghindari terjadinya sikap menunda- nunda pekerjaan sehingga membuat waktu yang terbuang (tidak efektif), maka perlu adanya kontrol terhadap waktu. Atau dengan kata lain siswa dapat menentukan prioritas berdasarkan jenis waktu yaitu penting dan mendesak, penting namun tidak mendesak, tidak penting namun mendesak serta tidak penting dan tidak mendesak.

2. Teknik Pembuatan To Do List. Hal ini diperlukan untuk melakukan perencanaan, penjadwalan perilaku agar menurunkan tingkat prokrastinasi akademik siswa. Hal ini bermanfaat bagi siswa untuk membuat penjadwalan kegiatan belajar dimulai dari hari Senin hingga Jumat sehingga siswa memiliki gambaran mengenai jadwal kegiatannya dalam satu minggu kedepan sehingga diharapkan siswa dapat belajar serta mengerjakan tugas dengan tepat waktu.

3. Teknik Pilihan Terhadap Pengorganisasian. Teknik ini diperlukan untuk mempermudah siswa dalam menyelesaikan pekerjaan sekolah dengan tepat waktu, tidak merusak jadwal kegiatan yang telah disusun dan tidak membantu tercapainya tujuan yang telah ditetapkan. Dalam teknik ini terdapat beberapa pertanyaan yaitu "bentuk kegiatan", "hadiah jika berhasil dilakukan" dan "konsekuensi jika tidak berhasil dilakukan”. Dengan teknik ini diharapkan siswa mampu menyadari kegiatan yang penting atau bermanfaat maupun kegiatan yang kurang bermanfaat bagi dirinya, hal ini juga dapat membantu para siswa untuk konsisten dalam melakukan kegiatan khususnya yang bermanfaat bagi dirinya.

Pada Psikoedukasi Prokrastinasi yang dilakukan kepada siswa SMP, SMA maupun SMK, diberikan psikoedukasi berupa teknik- teknik yang dapat digunakan siswa untuk mempermudah dalam mengerjakan tugas sekolah, mengatur waktu belajar. Hal ini dapat membantu siswa untuk menentukan prioritas sehingga dapat menurunkan tingkat prokrastinasi akademik. Hal ini dilakukan mengingat tingginya tingkat prokrastinasi akademik yang terjadi selama sekolah online atau "belajar di rumah" akibat pandemi Covid-19 yang terjadi di Indonesia. 
Psikoedukasi "PePro" untuk menurunkan prokrastinasi akademik dengan menggunakan manajemen waktu yang diberikan kepada peserta dapat menambah pengetahuan mengenai prokrastinasi serta keterampilan dalam memanajemen waktu. Cara atau teknik manajemen waktu yang diberikan oleh kakak pembimbing merupakan cara yang mudah untuk diterapkan sendiri oleh siswa SMP, SMA dan SMK serta tidak mengeluarkan biaya untuk melakukannya. Pembuatan kuadran Covey, to do list dan tabel konsekuensi dapat peserta kreasikan sendiri sesuai dengan keinginannya agar terlihat lebih menarik sekaligus dapat membangkitkan kreativitas peserta.

Terdapat beberapa cara yang dilakukan oleh peneliti untuk mengevaluasi kegiatan psikoedukasi ini, yaitu berdasarkan hasil pretest dan posttest, pemantauan to do list, sesi sharing dan melalui google form. Berdasarkan hasil pretest yang telah dilakukan peneliti menggunakan alat ukur prokrastinasi akademik dengan aspek Ferrari (1995) didapatkan hasil skor pretest dan posttest.

Tabel 4. Hasil Total Pretest dan Posttest Perilaku Prokrastinasi Akademik

\begin{tabular}{ccc}
\hline Aspek & $\begin{array}{c}\text { Skor } \\
\text { Pretest }\end{array}$ & $\begin{array}{c}\text { Skor } \\
\text { Posttest }\end{array}$ \\
\hline $\begin{array}{l}\text { Penundaan untuk } \\
\text { memulai maupun }\end{array}$ & 368 & 432
\end{tabular}

\begin{tabular}{lcc}
\hline \multicolumn{1}{c}{ Aspek } & $\begin{array}{c}\text { Skor } \\
\text { Pretest }\end{array}$ & $\begin{array}{c}\text { Skor } \\
\text { Posttest }\end{array}$ \\
\hline $\begin{array}{l}\text { menyelesaikan kerja } \\
\text { pada tugas yang } \\
\text { dihadapi }\end{array}$ & & \\
$\begin{array}{l}\text { Keterlambatan } \\
\text { dalam mengerjakan } \\
\text { tugas }\end{array}$ & 362 & 419 \\
\hline
\end{tabular}

Kesenjangan waktu yang dimilikinya 370 399 antara rencana dengan kinerja aktual Melakukan aktivitas 572 556

lain yang lebih menyenangkan daripada menyelesaikan tugas yang harus dikerjakan

\begin{tabular}{rrr}
\hline Total & 1672 & 1806 \\
\hline
\end{tabular}

Semakin rendah skor prokrastinasi yang didapatkan maka semakin rendah pula tingkat prokrastinasi yang dimiliki. Sebaliknya, jika semakin tinggi skor yang diperoleh maka hal tersebut menunjukkan semakin tinggi pula tingkat prokrastinasi yang dimiliki oleh peserta. Berdasarkan hasil tabel diatas diketahui bahwa terjadi peningkatan antara skor pretest dengan posttest, diketahui bahwa tiga aspek mengalami peningkatan dari hasil pretest. Kecuali pada aspek terakhir yaitu "melakukan aktivitas lain yang lebih menyenangkan daripada menyelesaikan tugas yang harus dikerjakan”. Hal tersebut menyatakan bahwa setelah pemberian psikoedukasi para siswa mulai dapat menyelesaikan tugas dan tidak 
mementingkan aktivitas yang dianggap menyenangkan. Walaupun secara keseluruhan terdapat peningkatan skor dari pretest dan posttest.

Jika dilihat dari rata-rata skor angket, terjadinya kenaikan skor rata-rata pada perilaku prokrastinasi dapat membuktikan jika psikoedukasi yang dilakukan tidak efektif untuk menurunkan prokrastinasi akademik yang dimiliki oleh siswa dikarenakan skor yang didapat tidak mengalami penurunan secara signifikan. Hal ini juga dapat disebabkan oleh intervensi yang dilakukan secara online sehingga peneliti tidak dapat memastikan secara langsung apakah peserta dapat memahami materi yang diberikan atau tidak. Peneliti juga tidak dapat mengawasi peserta secara langsung dalam pelaksanaan to do list yang menyebabkan ketidakpastian apakah peserta benar-benar melaksanakan kegiatannya sesuai dengan to do list atau tidak. Selain itu, terdapat peserta yang menyatakan bahwa dirinya belum pernah menerapkan teknik manajemen waktu dan ini merupakan kali pertamanya sehingga dirasa perlu waktu yang lebih lama agar mereka menjadi terbiasa dengan hal ini.

Cara selanjutnya adalah dengan melakukan sesi sharing antara peneliti dan peserta, lima hari setelah melakukan psikoedukasi, peneliti kembali menghubungi peserta, hal ini bertujuan agar peserta dapat membagikan ceritanya kepada peserta lain, selain itu dari sesi ini peneliti juga dapat mengetahui kemajuan peserta dalam memanajemen waktunya. Pada saat sesi sharing yang dilakukan selama 10 menit, peserta bercerita mengenai kegiatan-kegiatan yang dilakukannya pada 5 hari terakhir dan beberapa peserta juga mengakui bahwa kegiatan ini cukup menantang untuk dilakukan oleh dirinya dikarenakan ini merupakan pengalaman pertamanya. Berdasarkan hasil evaluasi, peserta mengatakan jika cara atau teknik yang diberikan oleh peneliti pada saat psikoedukasi dapat membantunya sedikit demi sedikit untuk menghindari melakukan prokrastinasi akademik.

Berdasarkan hasil pemantauan to do list selama 5 hari yang dilakukan melalui google docs, peserta telah melakukan seluruh kegiatannya sesuai dengan yang mereka tulis pada google form saat kegiatan psikoedukasi berlangsung. Terdapat beberapa peserta yang melakukan kegiatan lain selain yang mereka tulis pada to do list untuk mengisi waktu luangnya seperti bersepeda dan bermain dengan temannya. Evaluasi selanjutnya yaitu menggunakan google form yang berisi pertanyaan mengenai manfaat psikoedukasi, $88,2 \%$ menyatakan 
jika materi yang diberikan menarik, sesuai dengan kebutuhan dan bermanfaat bagi pengembangan diri peserta, 91,1\% menyatakan bahwa psikoedukasi ini dapat membantunya dalam penyelesaian tugas. Penilaian lainnya adalah pada aspek materi, pembawa materi, metode fasilitas psioedukasi, secara keseluruhan peserta memberikan nilai yang sangat baik dengan persentase diatas $50 \%$ pada masingmasing aspek.

\section{PENUTUP}

Berdasarkan analisis terhadap halhal yang diperoleh dalam pelaksanaan kegiatan PePro maka dapat disimpulkan jika manajemen waktu dapat efektif untuk mengurangi prokrastinasi hanya pada aspek "melakukan aktivitas lain yang lebih menyenangkan daripada menyelesaikan tugas yang harus dikerjakan", namun tidak efektif untuk menurunkan prokrastinasi pada aspek lainnya. Hal ini mungkin disebabkan karena banyaknya jumlah butir yang ada saat pemberian post test sehingga membuat angka skor pada post test meningkat serta peserta tidak memperhatikan kondisi yang sebenarnya yang dirasakan saat menjawab post test. Berdasarkan hasil diskusi dengan beberapa peserta alasan mereka belum terbiasa membuat jadwal teratur untuk belajar dan dirinya mengaku lebih menyukai cara belajar yang tidak ditentukan atau di target setiap harinya. Beban tugas yang diberikan sekolah dianggap terlalu banyak sehingga dirinya melakukan penundaan agar tidak terlalu merasa terbebani oleh sekolah dengan sistem pembelajaran jarak jauh. Dampak dari diadakannya psikoedukasi "PePro" untuk menurunkan prokrastinasi akademik dengan menggunakan manajemen waktu yang dapat diperoleh peserta yaitu:

1. Peserta mengetahui dan memahami mengenai prokrastinasi akademik dan manajemen waktu

2. Peserta mampu menentukan kegiatan penting, tidak penting, mendesak dan tidak mendesak serta menuliskannya

3. Peserta mampu membuat to do list kegiatan yang akan dilakukan sehari-hari

4. Peserta mampu menentukan self reward dan konsekuensi kegiatannya

Saat ini proses psikoedukasi telah dijalankan secara terstruktur dan berjalan lancar kepada siswa SMP, SMA maupun SMK.

Saran yang dapat diberikan untuk penelitian selanjutnya adalah lebih memperhatikan jumlah dan bunyi butirbutir dari alat ukur yang digunakan, agar benar-benar mengukur hal yang tepat sehingga peserta dapat menjawab sesuai 
dengan kondisinya. Selain itu, penelitian selanjutnya akan mendapatkan hasil yang maksimal jika dilakukan lebih dari satu kali agar peserta dapat terbiasa untuk memanajemen waktunya. Penelitian selanjutnya juga dapat menggunakan alternatif lain untuk menurunkan prokrastinasi seperti self control.

\section{DAFTAR PUSTAKA}

Fauziah, H. H. (2015). Faktor-Faktor yang Mempengaruhi Prokrastinasi Akademik pada Mahasiswa Fakultas Psikologi UIN SGD Bandung (Hana Hanifah Fauziah). Psympathic : Jurnal Ilmiah Psikologi, 2(2), 123132. doi: $10.15575 /$ psy.v2i2.453
Ferrari, J. R., Jhonson, J. L., \& McCown, W. G. (1995). Procrastination and task avoidance. theory, research and treatment. Lawrence, Kansas: Plenum Press

Hastuti, D. D., Sutama, \& Fuadi, D. (2018). Tanggung Jawab Siswa dalam Pembelajaran Matematika SMA. Jurnal Manajemen Pendidikan, 13(2), 139-146.

Kartadinata, I., \& Tjundjing , S. (2008). I Love You Tomorrow: Prokrastinasi Akademik dan Manajemen Waktu . Anima, Indonesian Psychological Journal, 109-119.

Tim Dosen Administrasi Pendidikan UPI, Manajemen Pendidikan, (Bandung: Alfabeta, 2009), h. 205 